\title{
Tsumoite and associated tellurides from the Au deposit Libčice near Nový Knín, Czech Republic: mineralogy and genetic significance
}

\author{
Jiří SEJKORA", Jiří LITOCHLEB'1, Jakub PLÁŠIL1', Bohuslav BUREŠ² \\ ${ }^{1}$ Department of Mineralogy and Petrology, National Museum, Václavské nám. 68, 11579 Prague 1, Czech Republic; jiri_sejkora@nm.cz \\ ${ }^{2}$ Plevenská 3111, 143 00, Prague 4, Czech Republic \\ * Corresponding author
}

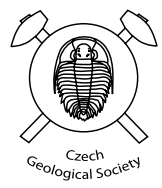

A mineral association with dominant pyrrhotite, tsumoite and gold, accompanied by minor tetradymite and pilsenite, has been found in material from the main vein of the abandoned Au deposit Libčice near Nový Knín, $25 \mathrm{~km} \mathrm{SSW} \mathrm{of} \mathrm{Prague,}$ central Bohemia, Czech Republic. Tsumoite forms abundant silvery grey tabular aggregates up to 1-4 mm in size. The mineral is grey-white to very weakly beige-coloured in reflected light, anisotropic, with VHN microhardness 68 (63-76) $\mathrm{kg} / \mathrm{mm}^{2}$, with $\mathrm{K}_{\mathrm{VH}}=1.21$. Chemical analyses (electron microprobe) of matrix tsumoite yield $\mathrm{Pb}=0.27, \mathrm{Cd}=0.12$, $\mathrm{Bi}=61.12, \mathrm{Te}=37.97, \mathrm{~S}=0.01$ and total of $99.50 \mathrm{wt} . \%$, which corresponds to an empirical formula of $\mathrm{Bi}_{0.99} \mathrm{Te}_{1.00}$ based on $2 \mathrm{apfu}$. The chemical composition of Bi-rich schlieren-like domains within the tsumoite is $\mathrm{Pb} 0.20, \mathrm{Cd} \mathrm{0.09,} \mathrm{Bi} 63.06$, Te 36.44, S 0.01, total $99.80 \mathrm{wt}$ \% , and corresponds to empirical formula $\mathrm{Bi}_{1.02} \mathrm{Te}_{0.97}$ on the basis of 2 apfu. Both compositional varieties of tsumoite exhibit relatively small non-stoichiometry in Bi:Te ratio with respect to the ideal formula. The observed compositional range of tsumoite from Libčice corresponds to data published for this mineral species. Tsumoite is trigonal with space group $P-3 m 1$ and unit-cell parameters $a$ 4.4204(9)-4.4210(8), c 24.043(7)-24.055(6) $\AA$, $V$ 406.9(1)-407.2(1) $\AA^{3}$. Pilsenite forms rare cleavable aggregates up to $80 \mu \mathrm{m}$. Its chemical composition $\mathrm{Pb} 0.09$, $\mathrm{Cd}$ 0.12, Bi 67.63, Te 31.46, total 99.30 wt. \% yields the empirical formula $\left(\mathrm{Bi}_{3.96} \mathrm{Cd}_{0.01} \mathrm{~Pb}_{0.01}\right)_{\Sigma 3.99} \mathrm{Te}_{3.02}$ (based on 7 apfu). Younger tetradymite occurs in tiny irregular aggregates which partly overgrew and replaced tsumoite in association with native gold along fractures. The chemical composition of the tetradymite $-\mathrm{Pb}=0.04, \mathrm{Cd}=0.11 \mathrm{Bi}=59.07$, $\mathrm{Te}=36.08, \mathrm{~S}=4.50$, total $=99.78$ wt. $\%$ - corresponds to an empirical formula $\left(\mathrm{Bi}_{2.00} \mathrm{Cd}_{0.01}\right)_{\Sigma 2.01} \mathrm{Te}_{2.00} \mathrm{~S}_{0.99}($ based on $5 \mathrm{apfu}$ ). Associated pyrrhotite yielded formula $\mathrm{Fe}_{1-\mathrm{x}} \mathrm{S}$ with $\mathrm{x}$ values in the range $0.13-0.14$. Gold contains low $\mathrm{Ag}$ (up to 4 wt. \%) and $\mathrm{Hg}$ (up to $1 \mathrm{wt} . \%$ ). The studied mineral association formed at elevated temperatures $\left(>30{ }^{\circ} \mathrm{C}\right)$, probably at two stages differing in bismuth activity, as well as $\mathrm{f}_{\mathrm{S} 2}$ and $\mathrm{f}_{\mathrm{Te} 2}$ values. Alternatively, the two stages could have reflected variation of hydrothermal and metamorphic process in space and time.

Keywords: Bismuth-tellurides, tsumoite, X-ray powder diffraction data, chemical composition, Libčice gold deposit, Czech Republic Received: 19 January 2009; accepted 8 April 2009; handling editor: R. Skála

\section{Introduction}

Bismuth-tellurides and Bi-sulphotellurides are characteristic accessory minerals of gold, gold-copper and base metal ore deposits of magmatic, hydrothermal and metamorphogenic type. The investigations of formation conditions and crystal chemistry (in particular the scope of possible non-stoichiometry and disorder character of crystal structure) brings information on ore genesis. For this reason, these minerals have been intensively studied recently (Gu et al. 2001; Ciobanu et al. 2006, 2009a; Cook and Ciobanu 2004; Cook et al. 2007a, 2007b; Parafiniuk et al. 2008; Tooth et al. 2008 and others).

Tsumoite, BiTe, first described in 1978 on material from the type-locality Tsumo $\mathrm{Cu}-\mathrm{Zn}-\mathrm{Pb}$ skarn deposit, Japan (Shimazaki and Ozawa 1978), belongs to the tetradymite group of Bi-tellurides. The main problem in nomenclature of minerals in the $\mathrm{Bi}-\mathrm{Te}$ system relates to papers of Bayliss (1991), which presumed that there exists a single solid-solution phase (Bi-rich tsumoite) with $\mathrm{Bi}$ and $\mathrm{Te}$ in proportions of 1.35 to 2.61 . This presumption of the character of Bi-for-Te substitution has not been confirmed by new data. In difference to some other discontinuous solid solution series in the $\mathrm{Bi}-\mathrm{Te}-\mathrm{Se}-\mathrm{S}$ system (Ciobanu et al. 2009b), tsumoite exhibits perfect stoichiometry in majority of occurrences or shows limited compositional variation with $c .42-50$ at. \% Te, corresponding to solidsolution of tsumoite phase in the binary system Bi-Te (Okamoto and Tanner 1990). According to Cook et al. (2007b), even in this narrow range there are several discrete phases (known from synthesis experiments), such as $\mathrm{Bi}_{8} \mathrm{Te}_{7}, \mathrm{Bi}_{22} \mathrm{Te}_{21}, \mathrm{Bi}_{32} \mathrm{Te}_{33}, \mathrm{Bi}_{14} \mathrm{Te}_{15}, \mathrm{Bi}_{26} \mathrm{Te}_{29}$ and $\mathrm{Bi}_{8} \mathrm{Te}_{9}$ with 46.7, 48.8, 50.8, 51.7, 52.7 and 52.9 at. $\%$ Te. Broader solid-solution for tsumoite (exceeding the range of $42-50$ at. $\% \mathrm{Te}$ ) has been described by Dobbe (1991) for Bi-Te compounds from Tunnaberg, Sweden, and by Cabri and Laflamme (1976) for "wehrlite" from $\mathrm{Cu}-\mathrm{Ni}$ deposits of the Sudbury area, Canada. However, it 
is probable that some of the chemical analyses published in these papers correspond to other minerals in the tetradymite group (e.g. hedleyite, pilsenite, unnamed $\mathrm{Bi}_{2} \mathrm{Te}$ etc.) (Cook et al. 2007b) or they may result from disorder on the lattice scale with nanoscale domains of structures with different composition (Ciobanu et al. 2009b).

Tsumoite occurrences in the Czech Republic have been described on the basis of energy dispersive microanalysis of microscopic aggregates (inclusions up to several $\mu \mathrm{m}$ across and microscopic intergrowth aggregates with other opaque minerals) in material from the gold deposits at Kašperské Hory (Scharmová and Pertoldová 1990) and Vacíkov-Petráčkova hora (Pertoldová and Šulcová 1994) as well as from the Zadní Chodov uranium deposit (Scharmová 1998). Tsumoite has also been described as inclusions up to $30 \mu \mathrm{m}$ in size, in association with Pd minerals and native bismuth in $\mathrm{Cu}-\mathrm{Ni}$ sulphide mineralization at Staré Ransko deposit (Vavř́n et al. 1997; Vavř́n and Frýda 1998; Pašava et al. 2003). The first occurrence in the Czech Republic of a macroscopic intergrowth of tsumoite with tetradymite and tellurobismutite was described by Litochleb et al. (2005) from gold-bearing quartz veins at Bytíz-Staré hory, near Př́bram.

\section{Geological setting}

The Libčice deposit is situated on the eastern slopes of the Hořice hill west of Libčice, $c$. $4 \mathrm{~km}$ south of the town of Nový Knín in central Bohemia, Czech Republic. It represents a locality with the largest gold accumulation in the Nový Knín gold-bearing area with estimated historical production of two tons Au. Mining took place mainly during the Middle Ages, with the last activity during the first half of the $20^{\text {th }}$ century. Workings reached a depth of nearly $200 \mathrm{~m}$ in the Middle Ages and belong thus, besides the Jílové gold-bearing district, to the deepest ones in Bohemia (Litochleb 1976, 2003). Exploration of deeper levels (from 300 to $400 \mathrm{~m}$ ) started in 1945 and was terminated in 1957 (Malachov 1953; Havlíček 1959).

The deposit is located in the Dražetice volcanic body (dacite) of the Kozí Hory Belt and in tuffitic schists of Neoproterozoic age. At the eastern flank, and toward deeper levels, the intrusive body of the Variscan Libčice biotite granite of Central Bohemian Pluton limits the deposit and was responsible for its thermal metamorphism. Mineralization of the vein type is tied to steep lamprophyre dykes with two different trends. The main Libčice vein (known under historical name Mladá Kamlová Zone; Amort 1942) follows an east-west trending spessartite dyke. A second vein trend (Stará Kamlová Zone) accompanies north-south trending kersantite dykes. Both spessartite and kersantite dykes are older than ore mineralization and obviously than the Libčice biotite granite (Morávek et al. 1992). These gold deposits are now considered examples of the so-called RIRG (reduced intrusion-related gold) type of gold deposits (Zachariáš et al. 2001). In contrast with other Au deposits of the Bohemian Massif, Au ore mineralization and surrounding rocks of the Libčice deposit were clearly thermally metamorphosed by the younger Libčice biotite granite.

The Libčice main vein with a steep dip of $75-90^{\circ}$ to the north was opened at the level of seven galleries to a depth of nearly $400 \mathrm{~m}$ below surface. The main parts of the vein have been exploited to a depth of $200 \mathrm{~m}$. The mineralized parts of the vein form a steep ore column 250-350 m long, bound at depth by the contact to the granite intrusion. In the east and west, the ore column is limited by wedging-out of the quartz vein and the host lamprophyre dyke. Shallow dip of the granite contact toward the west results in a wide zone of contact metamorphism of Neoproterozoic rocks and gold-bearing veins. The older age of the lamprophyre and gold-bearing vein is documented by the presence of their xenoliths in granite in a distance up to several metres from the contact (Pivec and Šrein 1987). The vein of massive grey-white quartz is on average $0.2-0.3 \mathrm{~m}$ wide, locally it exceeds $1 \mathrm{~m}$. The content of ore minerals is variable, usually low. Gold of a high fineness is typically finely disseminated but it forms some local macroscopic aggregates. Gold content is highly variable, values of 10-270 g Au/t, locally up to as much as $1,000 \mathrm{~g} \mathrm{Au} / \mathrm{t}$, were reported in old workings. There is a weak decline in the gold content with depth, but the width of veins is strongly reduced. The gold-bearing quartz vein is cut by flat lying dykes of aplite and pegmatite and disrupted by fractures trending $\mathrm{N}-\mathrm{S}$ and $\mathrm{E}-\mathrm{W}$, often filled by calcite (with palygorskite) or rare galena with sphalerite (Morávek 1958).

The granular texture of vein quartz and the presence of contact metamorphic silicates (such as wollastonite, diopside and grossular-andradite) in mineralized quartz gangue indicate thermal recrystallization. The situation points to overprinting of hydrothermal products by magma-related thermal recrystallization and to specific minerogenetic conditions corresponding to epidote-amphibole or amphibole hornfels metamorphic facies.

Ore mineralization is characterized by abundant hexagonal pyrrhotite, less common pyrite, arsenopyrite and molybdenite, gold in two generations (gold I with 2-5 wt. \% Ag and younger gold II with $12-13$ wt. \% Ag), and fine-grained aggregates of Bi-tellurides (Malec et al. 1985; Litochleb and Šrein 1994; Šrein et al. 1995). Zachariáš et al. (1997) proposed the following crystallization succession: quartz I, pyrrhotite $\rightarrow$ arsenopyrite I, pyrite I $\rightarrow$ loellingite $\rightarrow$ gold, Bi-tellurides, calcite I $\rightarrow$ quartz II, (Co-) arsenopyrite II, pyrite II, gold II, $\mathrm{CoSbS} \rightarrow$ pyrrhotite, chalcopyrite, tetrahedrite $\rightarrow$ pyrite III, calcite II, quartz III. 
Previous studies at this deposit resulted in the description of several minerals belonging to the Bi-tellurides group. Slavík (1918) reported occurrences of so-called tellurobismuthite (rich finds at the third level). Besides that were identified tetradymite, joséite B (Šrein et al. 1995) and silvery white tabular crystals, ascribed, without compositional data, to 'wehrlite' (Sobotka 1959), later re-defined as pilsenite (Ozawa and Shimazaki 1982). The occurrence of $\mathrm{Au}$ and $\mathrm{Ag}$ tellurides, reported by Hofmann (1912), has not been confirmed by subsequent studies. According to Malec et al. (1985), these minerals most likely represent microscopic intergrowths of gold with Bi-tellurides.

\section{Analytical techniques}

Polished sections of the studied samples from Libčice were prepared for optical investigation, measurement of microhardness and chemical analysis using standard diamond polishing techniques. Optical properties in reflected light were observed with a Nikon Eclipse ME600 microscope. The Vickers microhardness of tsumoite was measured using a PMT-3 instrument with $15 \mathrm{~g}$ load (calibrated on halite crystal with $5 \mathrm{~g}$ load, indentor exposure $15 \mathrm{~s}$, average value was calculated from 20 measurements on three grains).

Back-scattered electron (BSE) images were acquired and quantitative chemical compositions of minerals determined with a Cameca SX100 electron microanalyzer (Faculty of Science, Brno) operated at the following conditions: wave-length dispersive analysis, $25 \mathrm{kV}, 20$ $\mathrm{nA}$, electron beam diameter less than $1 \mu \mathrm{m}$. The following standards were used: $\mathrm{Ag}\left(\mathrm{AgL}_{\alpha}\right), \mathrm{Au}\left(\mathrm{AuL}_{\alpha}\right), \mathrm{Bi}$ $\left(\mathrm{BiM}_{\beta}\right), \mathrm{Bi}_{2} \mathrm{Te}_{3}\left(\mathrm{TeL}_{\beta}\right), \mathrm{CdTe}\left(\mathrm{CdL}_{\beta}\right)$, chalcopyrite $\left(\mathrm{SK}_{\alpha}\right)$, $\mathrm{Cu}\left(\mathrm{CuK}_{\alpha}\right), \mathrm{FeS}_{2}\left(\mathrm{FeK}_{\alpha}\right)$, pararammelsbergite $\left(\mathrm{AsL}_{\beta}\right)$, $\mathrm{PbCl}_{2}\left(\mathrm{ClK}_{\alpha}\right)$, PbSe $\left(\mathrm{PbM}_{\alpha}, \mathrm{SeL}_{\beta}\right)$ and $\mathrm{Sb}\left(\mathrm{SbL}_{\beta}\right)$. The abundances of the above elements, if not included in analytical data tables, were measured, but the values were below the respective detection limit (0.01-0.03 wt. \% for individual elements). Measured data were corrected using the PAP software (Pouchou and Pichoir 1985).

A handpicked sample of tsumoite was used for powder $\mathrm{X}$-ray diffraction experiments. The continuous mode of the PANalytical X'Pert Pro powder diffractometer (Faculty of Science, Charles University, Prague) operating at $40 \mathrm{kV}$ and $40 \mathrm{~mA}$ with $\mathrm{X}^{\prime}$ Celerator detector was used. Firstly, the sample was measured at Bragg-Brentano geometry. The sample studied was placed onto the surface of a flat silicon monocrystal wafer from the suspension of acetone in order to minimize complicated background. The X-ray powder diffraction data were collected from $3^{\circ}$ to $75^{\circ} 2 \theta$ with integrated step of $0.02^{\circ} 2 \theta$ and virtual time per integrated step of 350 seconds. Later, small amount of sample powder was mounted on a thin glass fibre onto goniometric head and scanned in Debye-Scherrer's geometry. For unit-cell parameters the powder X-ray diffraction pattern was collected in the range of $6-75^{\circ} 2 \theta$ with $\mathrm{CuK \alpha}$ radiation (Ni-filter, integrated step $0.02^{\circ} 2 \theta$, virtual time $2500 \mathrm{~s}$, sample was rotated). In both cases, the position of each diffraction maxima was refined using profile shape function Pearson VII by software ZDS (Ondruš 1993) and was used for unit-cell parameter refinement by software of Burnham (1962) based on least-squares method.

\section{Results and discussion}

\subsection{Sample description}

The several studied samples were collected in 1955 on the $5^{\text {th }}$ level of the Libčice mine in the main vein of the deposit, west of the shaft, near the contact with the Libčice granite. The samples represent a fine-grained black-green, hornfels-like rock with nearly massive grey quartz, and showing slickenside surfaces. The rock contains irregular granular sulphide aggregates (pyrrhotite, pyrite, arsenopyrite) $0 . X$ to $5-10 \mathrm{~mm}$ in size, fine-grained deep yellow gold and abundant silvery to light yellowish flaky tsumoite aggregates $1-4 \mathrm{~mm}$ across. Bi-tellurides, gold and sulphides form mutual intergrowths.

\subsection{Tsumoite}

Tsumoite is by far the most abundant Bi telluride in the studied mineral association. Some parts of the samples contain tsumoite in amounts comparable to the most abundant sulphide - pyrrhotite. Tsumoite forms irregular platy aggregates $1-4 \mathrm{~mm}$ long, showing a weak cleavage. On fresh fracture the mineral has an imperfect and silvery white metallic lustre. Compared to other Bi tellurides (tetradymite, tellurobismuthite etc.) it is clearly darker. In reflected light tsumoite is grey-white with a weak creamy shade, under crossed polarizers it is weakly anisotropic and shows grey-brown colour effects.

Vickers microhardness $\mathrm{VHN}_{15 \mathrm{~g}}=68(63-76) \mathrm{kg} / \mathrm{mm}^{2}$ with anisotropy coefficient $\mathrm{K}_{\mathrm{vH}}=1.21$ was measured on the studied tsumoite. There are few such published data on tsumoite microhardness, because of the generally very fine grain size of the mineral. Shimazaki and Ozawa (1978) reported values $51-90 \mathrm{~kg} / \mathrm{mm}^{2}$, Pavlova et al. (1988) measured on tsumoite from BiTe- $\mathrm{Bi}_{3} \mathrm{~S}_{5}$ decomposition structures $\mathrm{VHN}_{20 \mathrm{~g}}=101(93-108) \mathrm{kg} / \mathrm{mm}^{2}$. This value is influenced by higher hardness of the intimately intergrown phase $\mathrm{Bi}_{3} \mathrm{~S}_{5}$. Litochleb et al. (2005) reported $\mathrm{VHN}_{15 \mathrm{~g}}=109(93-133) \mathrm{kg} / \mathrm{mm}^{2}$ with anisotropy 
coefficient $\mathrm{K}_{\mathrm{VH}}=1.43$. The differences in measured microhardness of tsumoite from the localities Bytíz-Staré hory (Litochleb et al. 2005) and Libčice (this study) relate to hardness anisotropy of the second order (reticular anisotropy) in sections with different crystallographic orientations. In sample from Libčice were measured sections approximately normal to the basal plane, showing lower microhardness, whereas that from Bytíz-Staré hory was cut nearly parallel to the basal plane. The measured values indicate that tsumoite shows usually a higher microhardness in comparison with other phases in the $\mathrm{Bi}-\mathrm{Te}-\mathrm{S}$ system.

A detailed examination of the BSE images resulted in the recognition of irregular schlieren-like domains in parts of tsumoite aggregates (Fig. 1). A lighter Bi-rich phase

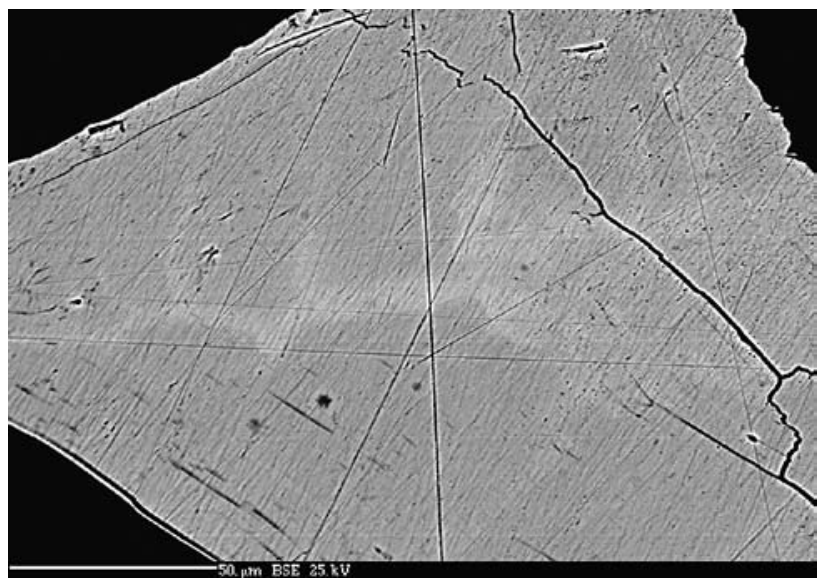

Fig. 1 A BSE image of irregular schlieren of lighter Bi-rich tsumoite passing gradually, without a clear boundary, into a matrix of darker tsumoite. of the schlieren passes gradually, without clear boundary, into darker Bi-poor matrix. Quantitative chemical analyses (Tab. 1) show that the tsumoite matrix (Figs 2-3) has the average Bi:Te ratios $0.99(0.94-1.04)$ and Te contents of 50.3 (48.5-51.5) at. \%. The empirical formula for matrix tsumoite (average of 27 spot analyses) is $\mathrm{Bi}_{0.99} \mathrm{Te}_{1.00}$, based on $2 a p f u$, i.e. perfect stoichiometry within the range of analytical error. The lighter schlieren with Bi:Te ratio $1.06(1.03-1.10)$ and $48.5(47.5-49.2)$ at. \% Te represent Bi-rich variant of tsumoite with empirical formula

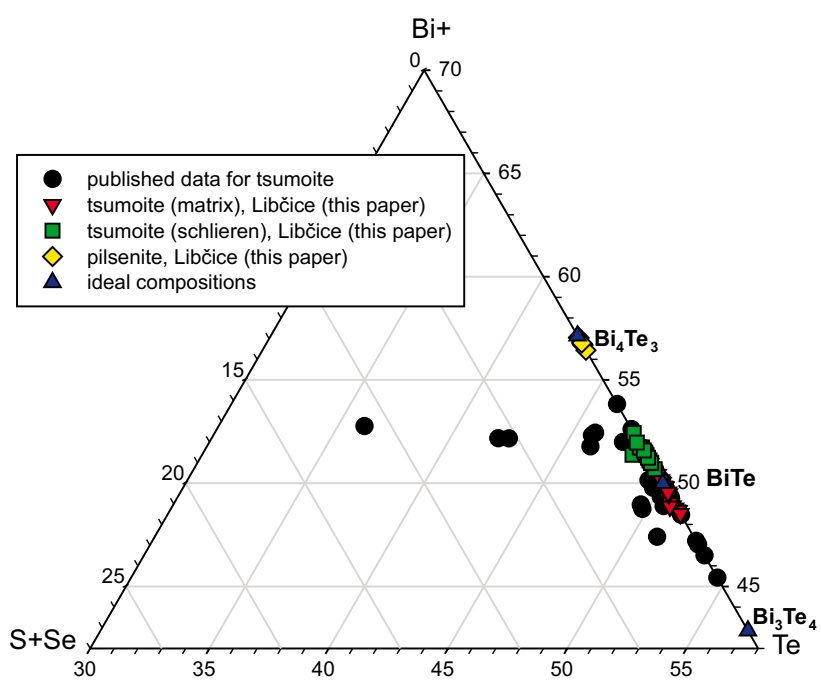

Fig. 2 Part of $\mathrm{Bi}+v_{s} \mathrm{Te} v_{s} \mathrm{~S}+\mathrm{Se}$ ternary plot for $\mathrm{Bi}$ tellurides from Libčice. $\mathrm{Bi}+=\mathrm{Bi}+\mathrm{Sb}+\mathrm{Pb}+\mathrm{Cd}+\mathrm{Ag}+\mathrm{Fe}+\mathrm{Cu}+\mathrm{Hg}$; published data for tsumoite are taken from papers of Shimazaki and Ozawa (1978), Zavjalov et al. (1978), Gamjanin et al. (1980), Gu et al. (2001), Cook and Ciobanu (2004), Ferenc (2004) and Litochleb et al. (2005).

Tab. 1 Representative chemical composition of two types of tsumoite from Libčice near Nový Knín (wt. \%). Number of atoms based on 2 apfu

\begin{tabular}{|c|c|c|c|c|c|c|c|c|c|c|c|c|c|c|}
\hline & \multicolumn{7}{|c|}{ tsumoite - matrix } & \multicolumn{7}{|c|}{ tsumoite - schlieren } \\
\hline & $\begin{array}{c}\text { mean }^{*} \\
(\mathbf{n}=27)^{*}\end{array}$ & range & 1 & 2 & 3 & 4 & 5 & $\begin{array}{c}\text { mean }^{*} \\
(\mathrm{n}=14)^{*}\end{array}$ & range & 1 & 2 & 3 & 4 & 5 \\
\hline $\mathrm{Pb}$ & 0.27 & $0.09-0.52$ & 0.43 & 0.27 & 0.18 & 0.23 & 0.15 & 0.20 & $0.14-0.32$ & 0.01 & 0.24 & 0.32 & 0.27 & 0.16 \\
\hline $\mathrm{Cd}$ & 0.12 & $0.03-0.36$ & 0.03 & 0.15 & 0.15 & 0.07 & 0.36 & 0.09 & $0.02-0.18$ & 0.18 & 0.11 & 0.12 & 0.05 & 0.02 \\
\hline $\mathrm{Bi}$ & 61.12 & $59.88-62.63$ & 59.90 & 60.84 & 61.23 & 61.80 & 62.63 & 63.06 & $62.47-64.33$ & 62.52 & 62.47 & 63.14 & 63.15 & 64.22 \\
\hline $\mathrm{Te}$ & 37.97 & $36.88-39.10$ & 39.09 & 38.83 & 37.50 & 37.79 & 36.88 & 36.44 & $35.40-37.22$ & 37.22 & 36.83 & 36.24 & 36.48 & 35.66 \\
\hline $\mathrm{S}$ & 0.01 & $0.00-0.05$ & 0.00 & 0.05 & 0.00 & 0.00 & 0.00 & 0.01 & $0.00-0.11$ & 0.00 & 0.00 & 0.11 & 0.00 & 0.00 \\
\hline Total & 99.50 & $98.50-100.77$ & 99.45 & 100.13 & 99.05 & 99.89 & 100.02 & 99.80 & $99.66-100.60$ & 99.93 & 99.66 & 99.92 & 99.94 & 100.07 \\
\hline $\mathrm{Pb}$ & 0.004 & & 0.007 & 0.004 & 0.003 & 0.004 & 0.002 & 0.003 & & 0.000 & 0.004 & 0.005 & 0.004 & 0.003 \\
\hline $\mathrm{Cd}$ & 0.004 & & 0.001 & 0.004 & 0.004 & 0.002 & 0.011 & 0.003 & & 0.005 & 0.003 & 0.004 & 0.001 & 0.001 \\
\hline $\mathrm{Bi}$ & 0.987 & & 0.963 & 0.971 & 0.995 & 0.996 & 1.011 & 1.024 & & 1.010 & 1.014 & 1.020 & 1.025 & 1.046 \\
\hline $\mathrm{Te}$ & 1.004 & & 1.029 & 1.015 & 0.998 & 0.998 & 0.975 & 0.969 & & 0.985 & 0.979 & 0.959 & 0.970 & 0.951 \\
\hline $\mathrm{S}$ & 0.001 & & 0.000 & 0.005 & 0.000 & 0.000 & 0.000 & 0.001 & & 0.000 & 0.000 & 0.012 & 0.000 & 0.000 \\
\hline Sum & 2.000 & & 2.000 & 2.000 & 2.000 & 2.000 & 2.000 & 2.000 & & 2.000 & 2.000 & 2.000 & 2.000 & 2.000 \\
\hline $\mathrm{Bi}: \mathrm{Te}$ & 0.99 & $0.94-1.04$ & 0.94 & 0.96 & 1.01 & 1.01 & 1.04 & 1.06 & $1.03-1.10$ & 1.03 & 1.04 & 1.06 & 1.06 & 1.10 \\
\hline
\end{tabular}

* mean and range of all measurements, followed by selected representative analyses 
Bi-telluride association from the Libcrice deposit

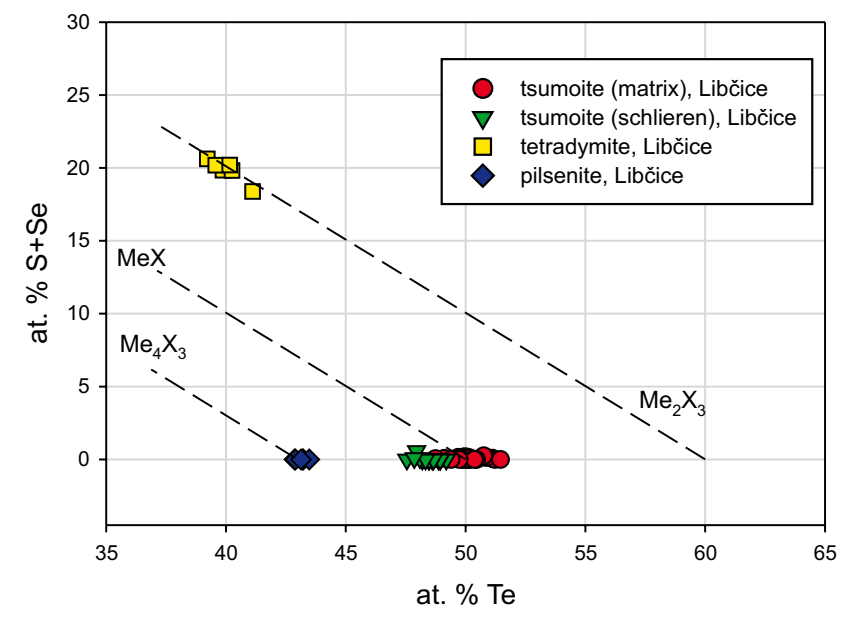

Fig. 3 Plot Te vs. S + Se (at. \%) for studied Bi tellurides and sulphotellurides.

$\mathrm{Bi}_{1.02} \mathrm{Te}_{0.97}$ (average of 14 spot analyses, based on 2 apfu). Yet, their composition falls within the range $42-50$ at. \% Te published for tsumoite solid solution in the binary system Bi-Te (Okamoto and Tanner 1990). The observed non-stoichiometry for tsumoite from Libčice probably indicates variation of conditions in the course of crystallization (such as changes in the Bi:Te ratio, temperature and/or pressure - Melnikov et al. 2005).

A X-ray powder diffraction pattern for tsumoite from Libčice was measured, beside the usual Bragg-Brentano setup, also using the Debye-Scherrer's geometry to reduce preferred orientation of the sample, caused by the perfect cleavage of the mineral. Decreasing relative intensity of the $00 l$ diffraction type maxima (Tab. 2) indicates that the use of Debye-Scherrer's geometry resulted in minimizing the preferred orientation effect. The obtained patterns correspond to theoretical values calculated from the BiTe crystal structure (Yamana et al. 1979) and data reported for natural tsumoite by Shimazaki and Ozawa (1978), Zavjalov et al. (1978) and Gamjanin et al. (1980). Refined unit-cell parameters for tsumoite from Libčice
Tab. 2 X-ray powder diffraction pattern of tsumoite from Libčice $(\AA)$

\begin{tabular}{|c|c|c|c|c|c|c|c|c|}
\hline \multirow[b]{2}{*}{$h$} & \multirow[b]{2}{*}{$k$} & \multirow[b]{2}{*}{$l$} & \multicolumn{2}{|c|}{ calculated data } & \multicolumn{2}{|c|}{ Bragg-Brentano } & \multicolumn{2}{|c|}{ Debye-Scherrer } \\
\hline & & & $d_{\text {calc. }}$ & $I_{\text {calc. }}$ & $d_{o b s .}$ & $I_{o b s .}$ & $d_{o b s .}$ & $I_{o b s .}$ \\
\hline 0 & 0 & 1 & 24.002 & 4 & & & & \\
\hline 0 & 0 & 2 & 12.001 & 1 & & & & \\
\hline 0 & 0 & 3 & 8.001 & 1 & & & & \\
\hline 0 & 0 & 5 & 4.800 & 4 & 4.798 & 28 & 4.806 & 15 \\
\hline 0 & 1 & 1 & 3.783 & 4 & 3.776 & 2 & 3.785 & 14 \\
\hline 0 & 1 & 3 & 3.455 & 1 & & & & \\
\hline 1 & 0 & 4 & 3.229 & 100 & 3.229 & 100 & 3.229 & 100 \\
\hline 1 & 0 & 6 & 2.767 & 1 & 2.775 & 2 & & \\
\hline 0 & 1 & 8 & 2.362 & 40 & 2.364 & 35 & 2.365 & 35 \\
\hline 1 & 1 & 0 & 2.212 & 36 & 2.211 & 7 & 2.212 & 21 \\
\hline 1 & 0 & 9 & 2.189 & 3 & 2.189 & 4 & 2.189 & 12 \\
\hline 0 & 1 & 10 & 2.034 & 1 & & & & \\
\hline 1 & 1 & 5 & 2.009 & 1 & 2.010 & 11 & 2.007 & 9 \\
\hline 1 & 1 & -5 & 2.009 & 1 & 2.010 & 11 & 2.007 & 9 \\
\hline 0 & 0 & 12 & 2.000 & 7 & 2.004 & 25 & 2.007 & 9 \\
\hline 2 & 0 & 1 & 1.909 & 1 & 1.908 & 2 & & \\
\hline 0 & 2 & 4 & 1.825 & 20 & 1.825 & 5 & 1.825 & 13 \\
\hline 0 & 1 & 13 & 1.663 & 2 & 1.665 & 4 & 1.666 & 8 \\
\hline 2 & 0 & 8 & 1.614 & 13 & 1.615 & 10 & 1.615 & 17 \\
\hline 0 & 2 & 9 & 1.556 & 1 & 1.556 & 2 & 1.557 & 11 \\
\hline 1 & 1 & 12 & 1.4834 & 9 & 1.4854 & 10 & 1.4851 & 20 \\
\hline 1 & 1 & -12 & 1.4834 & 9 & 1.4854 & 10 & 1.4851 & 20 \\
\hline 0 & 0 & 17 & 1.4119 & 1 & 1.4142 & 1 & 1.4126 & 3 \\
\hline 1 & 2 & -4 & 1.4074 & 9 & 1.4072 & 2 & 1.4064 & 17 \\
\hline 2 & 1 & 4 & 1.4074 & 9 & 1.4072 & 2 & 1.4064 & 17 \\
\hline 1 & 0 & 16 & 1.3968 & 6 & 1.4001 & 11 & 1.3984 & 5 \\
\hline 2 & 0 & 13 & 1.3292 & 1 & 1.3304 & 2 & 1.3293 & 1 \\
\hline 2 & 1 & -8 & 1.3039 & 6 & 1.3043 & 2 & 1.3042 & 13 \\
\hline 1 & 2 & 8 & 1.3039 & 6 & 1.3043 & 2 & 1.3042 & 13 \\
\hline 3 & 0 & 0 & 1.2768 & 6 & 1.2747 & 2 & 1.2749 & 9 \\
\hline
\end{tabular}

Theoretical data (with $\mathrm{I}_{\text {calc. }}>0.6$ ) were calculated by program Lazy Pulverix (Yvon et al. 1977) using the crystal structure information on synthetic tsumoite (Yamana et al. 1979)

Tab. 3 Unit-cell parameters of tsumoite indexed to the trigonal space group P-3m1

\begin{tabular}{|c|c|c|c|c|}
\hline & & $a[\AA ̊]$ & $c[\AA]$ & $V\left[\AA^{3}\right]$ \\
\hline Libčice BB* & this paper & $4.4210(8)$ & $24.055(6)$ & $407.2(1)$ \\
\hline Libčice D & this paper & $4.4204(9)$ & $24.043(7)$ & $406.9(1)$ \\
\hline synthetic & Yamana et al. (1979) & $4.423(2)$ & $24.002(6)$ & 406.6 \\
\hline Tsumo & Shimazaki and Ozawa (1978) & $4.422(2)$ & $24.05(2)$ & 407.3 \\
\hline Přibram-Bytíz & Litochleb et al. (2005) & $4.423(1)$ & 24.01(1) & $406.8(2)$ \\
\hline Burčaginkan & Zavjalov et al. (1978) & 4.427 & 24.06 & 408.4 \\
\hline Tyrnyauz & Zavjalov et al. (1978) & 4.425 & 24.04 & 407.6 \\
\hline Ilkovcy-Podulky & Zavjalov et al. (1978) & 4.421 & 24.06 & 407.2 \\
\hline Tyrnyauz & Zavjalov et al. (1978) & 4.411 & 24.18 & 407.4 \\
\hline Miller-Kopper & Zavjalov et al. (1978) & 4.408 & 24.18 & 406.9 \\
\hline Alekseevskoje & Zavjalov et al. (1978) & 4.408 & 24.18 & 406.9 \\
\hline
\end{tabular}

"BB - Bragg-Brentano, D - Debye-Scherrer geometries 
(Tab. 3) compare closely with data published for this mineral. Differences in parameters obtained using the two measurement geometries are in the range of calculated standard deviations.

\subsection{Tetradymite}

In the studied mineral association tetradymite is younger than tsumoite and comparatively rare. Typically it forms irregular minute aggregates $(1-10 \mu \mathrm{m})$, which partly overgrow and replace older tsumoite associated with gold (Fig. 4). Examples of irregular aggregates of tsumoite up to $100 \mu \mathrm{m}$, almost completely replaced by tetradymite and gold, are scarce (Fig. 5). Tetradymite in intergrowth with $\mathrm{Bi}-\mathrm{Te}$ phases is distinctly darker grey; it is anisotropic and shows bireflection with grey to grey-brown colour effects. Chemical composition of the

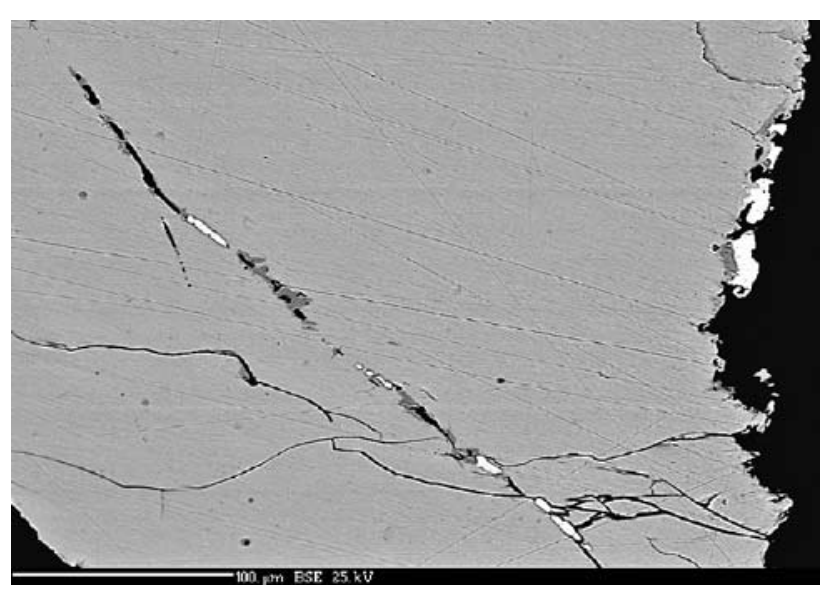

Fig. 4 Dark irregular aggregates of tetradymite, which penetrate along fractures, partly overgrow and replace older tsumoite (light grey) associated with gold (white) (BSE image).

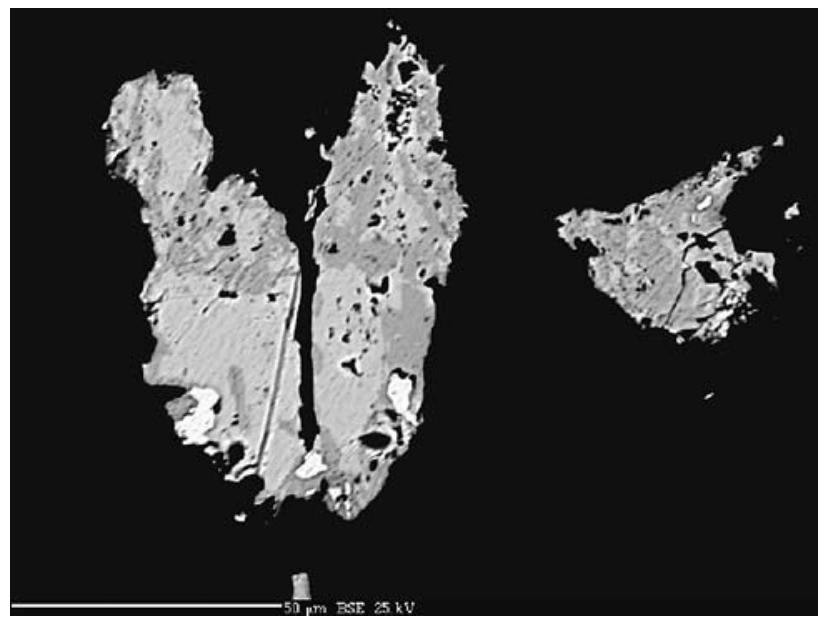

Fig. 5 Irregular tsumoite aggregates (light grey) extensively replaced by younger tetradymite (dark grey) and gold (white) (BSE image).

studied tetradymite (Tab. 4) is near the ideal composition of this mineral (Fig. 3). The Sb and Se are not present in detectable abundances, the maximum content of $\mathrm{Cd}$ is $0.01 \mathrm{apfu}$ and $\mathrm{Pb}$ content lower than $0.01 \mathrm{apfu}$. The average Te:S ratio $2.01(1.90-2.24)$ is near the theoretical 2:1. The empirical formula of tetradymite (average of 5 spot analyses) is $\left(\mathrm{Bi}_{2.00} \mathrm{Cd}_{0.01}\right)_{\Sigma 2.01} \mathrm{Te}_{2.00} \mathrm{~S}_{0.99}$, based on 5 apfu.

\subsection{Pilsenite}

Pilsenite has been observed as a single cleavable aggregate 70 by $80 \mu \mathrm{m}$ in size, intergrown with gold (Fig. 6) in quartz gangue. It is light grey in reflected light, compared to tsumoite it shows slightly higher reflectivity and under crossed polarizers it is weakly anisotropic (with grey-brown colour effects). Chemical composition of

Tab. 4 Chemical composition of tetradymite and pilsenite from Libčice (wt. \%). Number of atoms based on 5 apfu (tetradymite) and 7 apfu (pilsenite)

\begin{tabular}{|c|c|c|c|c|c|c|c|c|c|c|c|c|}
\hline & \multicolumn{6}{|c|}{ tetradymite } & \multicolumn{6}{|c|}{ pilsenite } \\
\hline & mean $(n=5)$ & 1 & 2 & 3 & 4 & 5 & mean $(n=5)$ & 1 & 2 & 3 & 4 & 5 \\
\hline $\mathrm{Pb}$ & 0.04 & 0.08 & 0.00 & 0.09 & 0.00 & 0.00 & 0.09 & 0.08 & 0.07 & 0.16 & 0.06 & 0.08 \\
\hline $\mathrm{Cd}$ & 0.11 & 0.11 & 0.14 & 0.17 & 0.08 & 0.04 & 0.12 & 0.08 & 0.12 & 0.16 & 0.13 & 0.11 \\
\hline $\mathrm{Bi}$ & 59.07 & 59.42 & 59.17 & 59.07 & 59.11 & 58.58 & 67.63 & 67.48 & 68.18 & 67.47 & 67.06 & 67.98 \\
\hline $\mathrm{Te}$ & 36.08 & 36.09 & 36.82 & 35.47 & 35.59 & 36.41 & 31.46 & 31.47 & 31.36 & 31.55 & 31.63 & 31.31 \\
\hline S & 4.50 & 4.51 & 4.14 & 4.69 & 4.55 & 4.60 & 0.00 & 0.00 & 0.00 & 0.00 & 0.00 & 0.00 \\
\hline Total & 99.78 & 100.22 & 100.25 & 99.48 & 99.33 & 99.63 & 99.30 & 99.11 & 99.73 & 99.33 & 98.87 & 99.48 \\
\hline $\mathrm{Pb}$ & 0.001 & 0.003 & 0.000 & 0.003 & 0.000 & 0.000 & 0.005 & 0.005 & 0.004 & 0.009 & 0.003 & 0.005 \\
\hline $\mathrm{Cd}$ & 0.007 & 0.007 & 0.009 & 0.011 & 0.005 & 0.003 & 0.013 & 0.008 & 0.013 & 0.017 & 0.014 & 0.012 \\
\hline $\mathrm{Bi}$ & 2.000 & 2.004 & 2.017 & 1.994 & 2.008 & 1.975 & 3.963 & 3.961 & 3.983 & 3.949 & 3.940 & 3.981 \\
\hline $\mathrm{Te}$ & 2.000 & 1.994 & 2.055 & 1.961 & 1.980 & 2.011 & 3.019 & 3.026 & 3.000 & 3.024 & 3.043 & 3.003 \\
\hline $\mathrm{S}$ & 0.992 & 0.992 & 0.919 & 1.031 & 1.007 & 1.012 & 0.000 & 0.000 & 0.000 & 0.000 & 0.000 & 0.000 \\
\hline Sum & 5.000 & 5.000 & 5.000 & 5.000 & 5.000 & 5.000 & 7.000 & 7.000 & 7.000 & 7.000 & 7.000 & 7.000 \\
\hline
\end{tabular}


pilsenite (Tab. 4) matches well the theoretical formula $\mathrm{Bi}_{4} \mathrm{Te}_{3}$ (Figs 2-3). Minor Cd corresponds to 0.01 apfu, $\mathrm{Pb}$ is lower than 0.01 apfu; $\mathrm{Sb}, \mathrm{S}$ and Se were not detected. Its chemical composition (average of 5 spot analyses) yields a theoretical formula $\left(\mathrm{Bi}_{3.96} \mathrm{Cd}_{0.01} \mathrm{~Pb}_{0.01}\right)_{\Sigma 3.98} \mathrm{Te}_{3.02}$, based on 7 apfu.

\subsection{Other ore minerals}

Gold forms tiny grains, dendritic aggregates up to $1 \mathrm{~mm}$ or occurs as thin coatings on wallrock fractures close to the quartz vein. Microscopic study shows that gold (A) forms subhedral grains up to $100 \mu \mathrm{m}$, which are older than the pilsenite (Fig. 6) or tsumoite (Fig. 7). In other places occur small irregular aggregates of younger gold (B), 5-30 $\mu \mathrm{m}$ across, which, together with tetradymite, are associated with earlier tsumoite (Figs 4-5). Gold is deep yellow in reflected light, and optically homogeneous, except for local and small tetradymite inclusions. The older generation of gold (A) with an average composition of Ag $=3.58$ (3.25-3.93), $\mathrm{Au}=94.69$ (93.83-95.63), $\mathrm{Hg}=0.72$ (0.30-1.08), $\mathrm{Cu}=0.14(0.11-0.17), \mathrm{Bi}=0.05$ (0.02-0.10) wt. \%, corresponds well to data published previously for older gold generation I from Libčice (Šrein et al. 1995; Zachariáš et al. 1997). Gold in intergrowth with pilsenite contains lower Ag (up to $0.061 \mathrm{apfu}$ ) and $\mathrm{Hg}$ (up to 0.005 apfu) than gold in association with tsumoite (Ag up to 0.070, Hg up to 0.010 apfu).

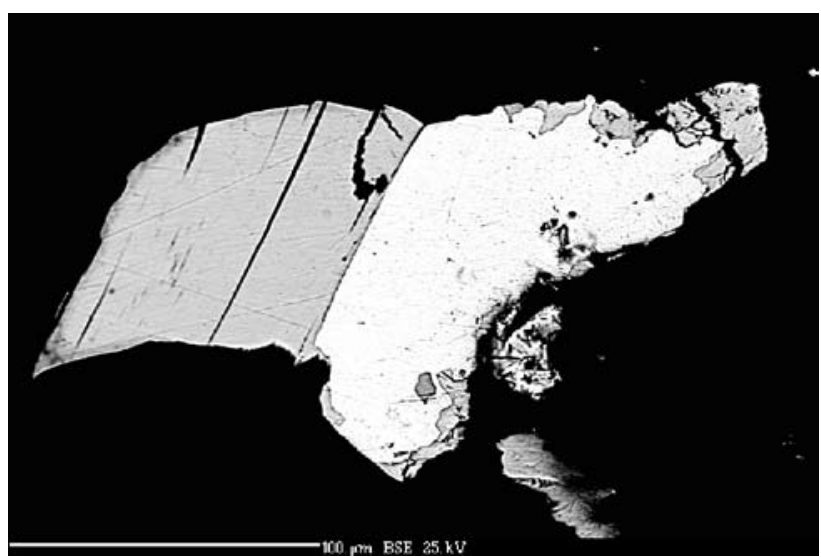

Fig. 6 Gold aggregate (white) overgrown by, and intergrown with, an aggregate of cleavable pilsenite (light grey). Tetradymite forms minute dark inclusions in gold (BSE image).

Hexagonal pyrrhotite strongly predominates in the studied mineral association. It forms fine-grained impregnations or irregular aggregates up to $1 \mathrm{~cm}$ in recrystallized quartz. Pyrrhotite has a metallic lustre and light beige-brown colour. In reflected light pyrrhotite is pinkish-brown, anhedral to subhedral and it is mostly replaced, except for small relics, by pyrite and

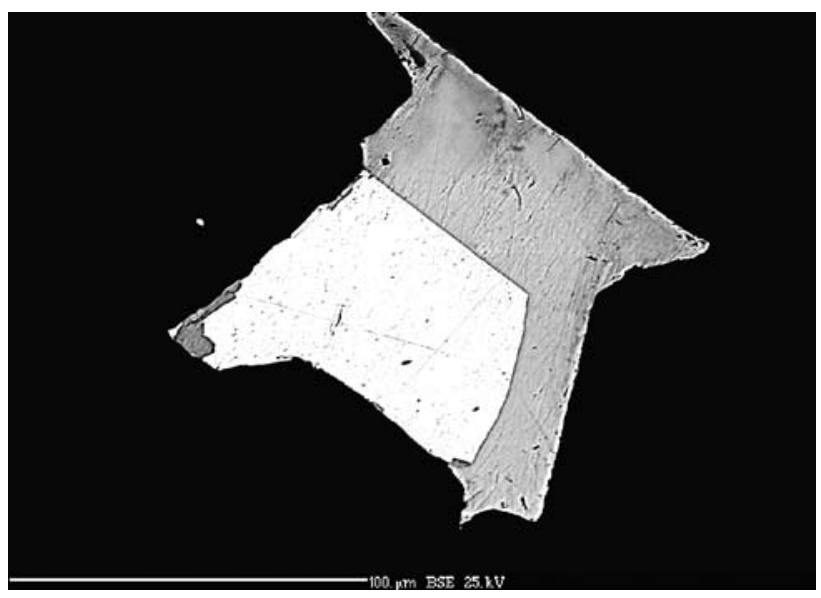

Fig. 7 Crystal of gold (white) overgrown by tsumoite (light grey) and replaced from the margins by tetradymite (dark grey) (BSE image).

arsenopyrite. Chemical composition is very simple as no additional elements are present in addition to $\mathrm{Fe}$ and $\mathrm{S}$ $(\mathrm{Fe}=59.65-59.75, \mathrm{~S}=39.48-40.01$, total 99.17-99.66 wt. \%). Iron content in pyrrhotite (calculated to 1 apfu $\mathrm{S}$ ) is 0.856-0.867 apfu, which for the empirical formula $\mathrm{Fe}_{1-\mathrm{x}} \mathrm{S}$ yields value $\mathrm{x}=0.13-0.14$. Such a composition falls in the range for natural pyrrhotites, for which $\mathrm{x}=0-0.17$ was reported (Anthony et al. 1990). No indications of transformation of pyrrhotite to marcasite have been observed either in reflected light or in BSE images. On the other hand, the alteration of pyrrhotite to marcasite is a characteristic feature of the younger (postmetamorphic) stages of mineralization in the studied vein (Šrein et al. 1995).

\section{Conditions of formation}

The studied mineralization with macroscopic $\mathrm{Bi}-\mathrm{Te}$ minerals and gold of high fineness belongs to $\mathrm{Au}-$ quartz mineralization, which is widespread throughout the Central Bohemian Metallogenetic Zone (Morávek et al. 1992). Compared to similar deposits and occurrences in this zone (e.g. Jílové near Prague, Nový Knín, MokrskoČelina), the studied locality differs by the presence of younger contact metamorphic phenomena, which affected the mineralogical composition, structure of the gangue and character of the ore mineralization.

The observed crystallization sequence: gold $\mathrm{A} \rightarrow$ tsumoite $(+$ pilsenite $) \rightarrow$ tetradymite $\rightarrow$ gold $\mathrm{B}$ and relative abundance of individual minerals permit to define at least two stages of crystallization in this mineral association. The more important first stage, which was responsible for deposition of pyrrhotite, gold A, tsumoite (both varieties) and pilsenite (all phases with ratio $\mathrm{Me} /(\mathrm{Te}+\mathrm{Se}+\mathrm{S}) \geq 1$ ) was characterized by high activity of bismuth at low 
values of $\mathrm{f}_{\mathrm{S} 2}$ (S-free Bi tellurides, presence of pyrrhotite) and locally variable but relatively high values $\mathrm{f}_{\mathrm{Te} 2}$ in hydrothermal fluids (Afifi et al. 1988; Cook and Ciobanu 2004 among others). The non-stoichiometry of the later tsumoite generation, the presence of its two chemically distinct varieties and the absence of native bismuth in the assemblage may indicate formation at elevated temperatures $\left(>300{ }^{\circ} \mathrm{C}\right)$ and somewhat variable conditions (e.g., changing Bi:Te ratio, temperature and/or pressure). Based on study of fluid inclusions from Libčice by Zachariáš et al. (1997), the following formation conditions were estimated for quartz and gold of the older generation: $\mathrm{T}=290$ to $310{ }^{\circ} \mathrm{C}$ and $\mathrm{P}=1.2-1.6$ kbar. Formation of the abundant older pyrrhotite probably resulted from metamorphic recrystallization of the original pyrite. The second stage, products of which are subordinate, is characterized by a replacement of the older $\mathrm{Bi}-\mathrm{Te}$ minerals by tetradymite, gold B, and by an origin of pyrrhotite of younger generation, pyrite and arsenopyrite. This development indicates a notable decline in Bi activity and an increase in $\mathrm{f}_{\mathrm{S} 2}$ in hydrothermal fluids (Affifi et al. 1988). A straightforward interpretation of minerogenesis at the Libčice deposit is significantly complicated by variable manifestations of hydrothermal and, especially, metamorphic processes in space and time. The two stages probably can represent a "primary" hydrothermal episode and a younger contact metamorphic (recrystallization) overprinting event.

\section{Conclusions}

A mineral association consisting of dominant pyrrhotite, tsumoite and gold, with accessory tetradymite and pilsenite, has been identified in high-grade gold ore from the main vein of the Libčice deposit. Study of chemical composition of tsumoite resulted in identification of its stoichiometric (predominating matrix) and a Bi-rich (in the form of schlieren) varieties. The compositional range of tsumoite from Libčice corresponds to data published for this mineral. Coexisting tetradymite and pilsenite are close to ideal stoichiometry, pyrrhotite is characterized by the formula $\mathrm{Fe}_{1-\mathrm{x}} \mathrm{S}$ with $\mathrm{x}$ values in the range 0.13-0.14; gold contains low $\mathrm{Ag}$ (up to 4 wt. \%) and $\mathrm{Hg}$ (up to 1 wt. \%) admixtures.

The studied mineral association formed at elevated temperatures $\left(>300{ }^{\circ} \mathrm{C}\right)$, probably in two stages with declining activities of bismuth and variable $\mathrm{f}_{\mathrm{S} 2}$ and $\mathrm{f}_{\mathrm{Te} 2}$. The origin of tetradymite after tsumoite and the replacement of older pyrrhotite by pyrite with arsenopyrite indicate a sulphidation of the assemblage in the second stage. The two stages probably represent a "primary" hydrothermal episode and a younger contact metamorphic (recrystallization) overprinting event.
Acknowledgements The authors thank Radek Škoda (Institute of Earth Sciences, Masaryk University, Brno) and Stanislav Vrána (Czech Geological Survey, Prague) for their kind help with the analytical work and language correction. The reviewers, Nigel John Cook and Yves Moëlo with handling editor Roman Skála are thanked for a number of constructive comments. The research was financially supported by the grants 205/06/0702 (Grant Agency of the Czech Republic) and MK00002327201 (Ministry of Culture of the Czech Republic).

\section{References}

Afifi AM, Kelly WC, Essene EJ (1988) Phase relation among tellurides, sulfides, and oxides: I. Thermochemical data and calculated equilibria; II. Applications to telluride-bearing ore deposits. Econ Geol 83: 377-394, 395-404

АмоRт Č (1942) "Kamlová“ gold mine near Nový Knín. Zpr Geol Úst pro Čechy a Moravu 12: 75-106 (in Czech)

Anthony JW, Bideaux RA, Bladh KW, Nichols MC (1990) Handbook of Mineralogy. Volume I. Elements, Sulfides, Sulfosalts. Mineral Data Publishing, Tucson, pp 1-588

BAYLISS P (1991) Crystal chemistry and crystallography of some minerals in the tetradymite group. Amer Miner 76: $257-265$

Burnham ChW (1962) Lattice constant refinement. Carnegie Inst Washington Year Book 61: 132-135

CABRI LJ, LAFLAMme JHG (1976) The mineralogy of the platinum-group elements from some copper-nickel deposits of the Sudbury area. Econ Geol 71: 1159-1195

Ciobanu CL, Cook NJ, Damian F, Damian G (2006) Gold scavenged by bismuth melts: an example from Alpine shear-remobilizates in the Highiş Massif, Romania. Mineral Petrol 87: 351-384.

Ciobanu CL, Cook NJ, Pring A, Brugger J, Danyushevsky LV, Shimizu M (2009a) "Invisible gold“" in bismuth chalcogenides. Geochim Cosmochim Acta 73: 1970-1999

Ciobanu Cl, Pring A, Cook NJ, Self P, Jefferson D, Dima GI, MeLniKov V (2009b) Chemical-structural modularity in the tetradymite group: a HRTEM study. Amer Miner 94: $517-534$

Cоoк NJ, Ciobanu CL (2004) Bismuth tellurides and sulphosalts from the Larga hydrothermal system, Metaliferi Mts., Romania: paragenesis and genetic significance. Mineral Mag 68: 303-321

Cook NJ, Ciobanu Cl, Stanley CJ, Paar Wh, Sundblad $\mathrm{K}$ (2007a) Compositional data for $\mathrm{Bi}-\mathrm{Pb}$ tellurosulfides. Can Mineral 45: 417-435

Cook NJ, Ciobanu CL, Wagner T, Stanley ChJ (2007b) Minerals of the system $\mathrm{Bi}-\mathrm{Te}-\mathrm{Se}-\mathrm{S}$ related to the tetradymite archetype: review of classification and compositional variation. Can Mineral 45: 665-708 
DobBe RTM (1991) Tellurides, selenides and associated minerals in the Tunaberg copper deposits, SE Bergslagen, central Sweden. Mineral Petrol 44: 89-106

FERENC Š (2004) New occurrences of tellurium minerals in western part of the Slovenské Rudohorie Mts. Miner Slov 36: 317-322 (in Slovak)

Gamjanin GN, Leskova NV, Vjal'sov LN, Laputina IP (1980) Bismuth tellurides - $\mathrm{Bi}_{2} \mathrm{Te}$ and $\mathrm{BiTe}-$ at occurrences of North-Eastern USSR. Zap Vsesojuz mineral Obšč 109: 230-235 (in Russian)

Gu X, Watanabe M, Hoshino K, Shibata Y (2001) Mineral chemistry and associations of $\mathrm{Bi}-\mathrm{Te}(\mathrm{S}, \mathrm{Se})$ minerals from China. Neu Jb Mineral, Mh 289-309

HavLíčeK J (1959) Final report Libčice near Nový Knín. Unpublished manuscript, Geofond Prague, pp 1-158 (in Czech)

Hofmann A (1912) Gold-bearing quartz veins near Libčice near Nový Knín. Rozpr Čes Akad Věd, Tř II 21: 1-12 (in Czech)

Litochleb J (1976) Mining enterprizing near Nový Knín. Sbor Symp Horn Př́ibram ve vědě a techn, Sekce k problémům vývoje rudného hornictví v dějinách ČSSR, pp 205-222 (in Czech)

Litochleв J (2003) History of gold mining in the Nový Knín area. In: Lhotský P, Morávek P, Štědrá V (eds) Zlato na Novoknínsku. Český klub zlatokopů, Česká geologická služba, Hornické muzeum Př́bram, Město Nový Knín, pp 14-23 (in Czech)

LitoChLEB J, Šrein V (1994) Bismuth and tellurium minerals in gold deposits and occurrences in the Czech Republic. Bull mineral-petrolog Odd Nár Muz (Praha) 2: 89-105 (in Czech)

Litochleb J, Sejkora J, Škácha J (2005) Tsumoite (BiTe) from gold-bearing quartz veins at Bytíz-Staré hory near Př́bram (central Bohemia). Bull mineral-petrolog Odd Nár Muz (Praha) 13: 150-153 (in Czech)

Malachov AA (1953) Final report Libčice near Nový Knín. MS, Geofond Praha (in Czech)

Malec J, Novák F, Blüml A, Litochleb J (1985) Mineralogical research of postmagmatic gold deposits in the Bohemian Massif. Progress Report. Unpublished manuscript, Geofond Prague, pp 1-122 (in Czech)

Melnikov VS, Bondarenko S, Grinchenko O (2005) Conditions of Bi-telluride formation in Vyghorlat Huta volcanic ridge, Transcarpathian region, Ukraine. Proceedings of the 2005 Field Workshop IGCP Project 486, Sofia. Geochem, mineral, petrol 43: 124-127

MorÁveK P (1958) Occurrences of new minerals in goldbearing veins of Central Bohemia. Čas Min Geol 3: 114 (in Czech)

MorÁvek P (ed.) (1992) Gold in the Bohemian Massif. Czech Geological Survey, Prague, pp 1-243 (in Czech) OкAmoto K, TANner LE (1990) Bi-Te (Bismuth-Tellurium). In Massalski TB, Окамото K (eds) Binary Alloy Phase
Diagrams 800-801. ASM International, Materials Park, Ohio

ONDRUŠ P (1993) ZDS - a computer program for analysis of X-ray powder diffraction patterns. Materials Science Forum, 133-136, EPDIC-2, Enchede. pp 297-300

Ozawa T, Shimazaki H (1982) Pilsenite re-defined and wehrlite discredited. Proc Japan Acad Ser B 58: 291-294

Parafiniuk J, Pieczka A, Golębiowska B (2008) Compositional data for ikunolite from Rędziny, Rudawy Janowickie, Lower Silesia, Poland. Canad Mineral 46: 1305-1315

PAŠAVA J, VAVŘín I, FrÝdA J, JANOUŠEK V, JeLÍNeK E (2003) Geochemistry and mineralogy of Platinum-group elements in the Ransko gabbro-peridotite massif, Bohemian Massif (Czech Republic). Mineral Depos 38: 298-311

Pavlova ZN, Žukov NM, Levin VL, Kotel'nikov PE, Tasov BM, Abulgazina SD (1988) Growth of decomposition structure type of tsumoite and $\mathrm{Bi}_{3} \mathrm{~S}_{5}$. Zap Vsesojuz mineral Obšč 117: 691-696. (in Russian)

Pertoldová J, Šulcová V (1994) Mineralogical research at the Vacíkov-Petráčkova hora locality, final report. Unpublished manuscript, appendix C 10 in STUDNIČNÝ et al. (eds) Final report Vacíkov, No. 2988 2101, raw materials $\mathrm{Au}(\mathrm{Cu}, \mathrm{W})$. Geofond, Prague (P 68 843) (in Czech)

Pivec E, Šrein V (1987) Petrological-geochemical study of the gold-bearing deposit Libčice. Unpublished manuscript, Ústav geologie a geotechniky ČSAV, Prague, pp 1-20 (in Czech)

Pouchou J L, Pichoir F (1985) "PAP" ( $\varphi \rho Z)$ procedure for improved quantitative microanalysis. In: ARMSTRONG JT (ed) Microbeam Analysis. San Francisco Press, San Francisco, 104-106

Shimazaki H, Ozawa T (1978) Tsumoite, BiTe, a new mineral from the Tsumo mine, Japan. Amer Miner 63: $1162-1165$

Scharmová M (1998) New selenide and telluride finds in the uranium deposits Zadní Chodov and Vítkov II (western Bohemia). Bull mineral-petrolog Odd Nár Muz (Praha) 6: 212-216 (in Czech)

Scharmová M, Pertoldová J (1990) Contribution to gold and bismuth mineralogy in the Kašperské Hory deposit. MEGA 14 (Zippe Vol): 146-164 (in Czech)

SLAvík F (1918) New finds of minerals in Bohemia. Čas Nár Muz 92: 38-42 (in Czech)

Sовотка J (1959) Preliminary report on occurrence of wehrlite, $\mathrm{Bi}_{2+\mathrm{x}} \mathrm{Te}_{3+\mathrm{x}}$, in Libčice near Nový Knín. Čas Min Geol 4: 99 (in Czech)

Šrein V, Pivec E, Langrová A (1995) Petrology and mineralogy of the gold-bearing deposit Libčice near Nový Knín. Bull mineral-petrolog Odd Nár Muz (Praha) 3: 188-195 (in Czech)

Tooth B, Brugger J, Ciobanu C, Liu W (2008) Modelling of gold-scavenging by bismuth melts coexisting with hydrothermal fluids. Geology 36: 815-818 
VAVŘín I, FRÝDA J (1998) Michenerite PdBiTe and froodite $\mathrm{PdBi}_{2}$ from the $\mathrm{Cu}-\mathrm{Ni}$ mineralization in the Ransko Massif, Czech Republic. Mineral Petrol 63: 141-146

VAVŘín I, FrÝdA J, JELíneK E (1997) Pd-Bi-Te mineralization occurrence at the deposit of copper-nickel ores in Staré Ransko. Zpr geol Výzk v R 1996: 187-188 (in Czech)

Yamana K, Kinara K, Matsumoto T (1979) Bismuth tellurides: BiTe and $\mathrm{Bi}_{4} \mathrm{Te}_{3}$. Acta Cryst B35: 147-149

Yvon K, Jeitschko W, Parthé E (1977) Lazy Pulverix, a computer program for calculating X-ray and neutron diffraction powder patterns. J Appl Cryst 10: 73-74

Zachariáš J, Pudilová M, Žák K, Morávek P, Litochleb J,
VÁŇA T, Pertold Z (1997) P-T conditions, fluid inclusions and $\mathrm{O}, \mathrm{C}, \mathrm{S}$ isotope characteristics of gold-bearing mineralizations within the Central Bohemian Metallogenic Zone. Acta Univ Carol, Geol 41: 167-178

Zachariáš J, Pertold Z, Pudilová M, Žák K, Pertoldová J, Stein M, Markey R (2001) Geology and genesis of Variscan porphyry-style gold mineralization, Petráčkova hora deposit, Bohemian Massif, Czech Republic. Miner Depos 36: 517-541

Zavjalov EN, Begizov VD, Stepanov VI (1978) Redetermination of wehrlite, the first occurrence of tsumoite in USSR. Zap Vsesojuz mineral Obšč 107: 544-553 (in Russian) 